\title{
ANALISIS KESALAHAN STRUKTUR KALIMAT \\ PADA TES KETERAMPILAN MENULIS DALAM DIKLAT HSK 3 (汉语水平考试) GURU BAHASA MANDARIN SMA/SMK DI PPPPTK BOE MALANG
}

\author{
Lestari Puspitaningsih \\ PPPPTK Bahasa, Kemendikbud \\ PPPPTK Bahasa,Jl.Gardu Srengseng Sawah Jagakarsa, Jakarta Selatan, Indonesia \\ Email: lestaripuspitaningsih@gmail.com
}

Submitted: 16-November-2018

Accepted : 31-December-2018
Published: 31-December-2018

DOI: 10.31540/silamparibisa.v1i2.151

URL: https://doi.org/10.31540/silamparibisa.v1i2.151

\begin{abstract}
Abstrak
Penelitian ini bertujuan untuk menganalisis kesalahan struktur kalimat pada tes keterampilan menulis yang dibuat oleh peserta diklat HSK 3 guru bahasa Mandarin SMA/SMK yang diselenggarakan di PPPPTK BOE Malang. Dalam Linguistik, berdasarkan J. Richard et al, (2002), kesalahan dapat berupakan kata, tindak tutur atau struktur gramatikal yang tidak tepat disebabkan oleh penguasaan yang tidak utuh terhadap bahasa tersebut. Penelitian dilakukan dengan menggunakan taksonomi komparatif yaitu menganalisis hasil tes keterampilan menulis peserta diklat yang terdapat pada HSK 3 yang disebabkan oleh kesalahan interlingual atau kesalahan interferensi, yakni kesalahan yang bersumber (akibat) dari pengaruh bahasa pertama (B1) terhadap bahasa kedua (B2) dan kesalahan intralingual yaitu kesalahan berbahasa yang disebabkan kurangnya penguasaan terhadap bahasa kedua (B2). Hasil anaslisis menunjukan bahwa terdapat lima kalimat dimana sebanyak lebih dari $85 \%$ responden melakukan kesalahan yang disebabkan adanya kerancuan dengan struktur dalam bahasa Indonesia. Analisis kesalahan ini dilakukan tidak hanya untuk mengidikasi penyebab, namun juga sebagai kajian untuk menerapakan metode yang sesuai dalam melaksanakan pembelajaran bahasa Mandarin.
\end{abstract}

Kata kunci: analisis kesalahan, taksonomi komparatif, HSK 3, Keterampilan Menulis

\section{ANALYSIS OF MISTAKE STRUCTURES MISTAKE IN WRITING SKILL TEST IN HSK CLASS 3 (汉语水平考试) MANDARIN HIGH SCHOOL/VOCATIONAL SCHOOL TEACHERS IN PPPPTK BOE MALANG}

\begin{abstract}
This study is aimed to investigate the types of sentence errors made by Mandarin High School Teachers who joint HSK 3 teacher training. In linguistics, according to J. Richard et al., (2002), an error is the use of a word, speech act or grammatical items in such a way it seems imperfect and significant of an incomplete learning. The study was conducted using a comparative taxonomy which was to analyze the results of training participants' writing skills tests contained in HSK 3 caused by interlingual errors or called also interference errors, where errors originating caused the influence of the first language (B1) on the second language languages (B2) and intralingual errors caused lack of understanding of the second language. Analysis results show that there are five sentences where as many as $85 \%$ of respondents make mistakes due to confusion with the structure in Indonesian. The occurrence of error analysis is don't only to indicate the cause, but also as a study for applying the appropriate method in implementing learning Mandarin.
\end{abstract}

Keywords: error analysis, comparative taxonomy, HSK 3, writing skills 


\section{A. Pendahuluan}

Pusat Pengembangan dan Pemberdayaan Pendidik dan Tenaga Kependidikan (PPPPTK ) Bahasa merupakan salah satu Unit Pelaksana Teknis di Lingkungan Direktorat Jenderal Guru dan Tenaga Kependidikan yang bertanggung jawab dalam mengembangkan perangkat dan melaksanakan peningkatan kompetensi guru sesuai bidangnya, yaitu guru bahasa Indonesia, Inggris, Perancis, Jerman, Arab, Jepang, dan bahasa Mandarin.

Guru wajib memiliki empat kompetensi yaitu (1) kompetensi profesional, (2) kompetensi pedagogik, (3) kompetensi sosial, dan (4) kompetensi kepribadian. Dalam kompetensi profesional, guru diharapkan mampu menguasai empat keterampilan berbahasa yaitu (1) keterampilan menyimak, (2) keterampilan berbicara, (3) keterampilan membaca, dan (4) keterampilan menulis. Salah satu bentuk dari perwujudan program peningkatan kompetensi untuk guru bahasa Mandarin adalah dengan menyelenggarakan Diklat Guru Bahasa Mandarin setara dengan HSK 3. HSK (Hanyu Shuiping Kaoshi) merupakan tes standar kemampuan bahasa Mandarin Internasional yang terdiri dari 6 level yang mana standar minimal kemampuan bahasa Mandarin yang harus dimiliki oleh guru bahasa Mandarin adalah setara dengan HSK level 3.

HSK 3 terdiri dari 3 bagian yaitu menyimak sebanyak 40 soal, membaca sebanyak 30 soal dan menulis sebanyak 15 soal. Pada bagian menulis terdapat 5 (lima) buah soal yang menguji kemampuan menyusun kalimat sesuai dengan struktur tata bahasa mandarin yang baik dan benar. Berdasarkan hasil perolehan nilai diketemukan bahwa hasil pada bagian tes keterampilan menulis lebih rendah dibandingkan perolehan nilai keterampilan menyimak dan keterampilan membaca. Menurut Javed, Juan, dan Nazli (2013:130) kemampuan menulis lebih sulit dibandingkan dengan kemampuan berbahasa lainnya karena kemampuan menulis mencakup kemampuan pemahaman kosakata dan struktur kalimat.

Untuk mengetahui penyebab terjadinya kesalahan dalam menjawab tes keterampilan menulis maka perlu dilakukan suatu analisis kesalahan terhadap hasil tes keterampilan menulis peserta diklat HSK 3. Chrystal (dalam Pateda 1989:32) mengungkapkan bahwa analisis kesalahan adalah sebuah teknik untuk 
mengidentifikasi atau menginterprestasikan sistematis kesalahan-kesalahan yang dibuat siswa yang sedang belajar bahasa asing atu bahasa kedua dengan menggunakan bahasa asing atau bahasa kedua dengan menggunakan teori-teori atau prosedur-prosedur berdasarkan linguitik.

Istilah kesalahan berbahasa memiliki pengertian yang beragam. Corder (1974) menggunakan 3 (tiga) istilah untuk membatasi kesalahan berbahasa: (1) Lapses, (2) Error, dan (3) Mistake. Ketiga istilah itu memiliki domain yang berbeda-beda dalam memandang kesalahan berbahasa. Corder (1974) menjelaskan: 1) Lapses, yaitu kesalahan berbahasa akibat penutur beralih cara untuk menyatakan sesuatu sebelum seluruh tuturan (kalimat) selesai dinyatakan selengkapnya. Untuk berbahasa lisan, jenis kesalahan ini diistilahkan dengan "slip of the tongue" sedang untuk berbahasa tulis, jenis kesalahan ini diistilahkan dengan "slip of the pen". Kesalahan ini terjadi akibat ketidaksengajaan dan tidak disadari oleh penuturnya.

2) Error, adalah kesalahan berbahasa akibat penutur melanggar kaidah atau aturan tata bahasa (breaches of code). Kesalahan ini terjadi akibat penutur sudah memiliki aturan (kaidah) tata bahasa yang berbeda dari tata bahasa yang lain, sehingga itu berdampak pada kekurangsempurnaan atau ketidakmampuan penutur. Hal tersebut berimplikasi terhadap penggunaan bahasa, terjadi kesalahan berbahasa akibat penutur menggunakan kaidah bahasa yang salah. 3) Mistake, adalah kesalahan berbahasa akibat penutur tidak tepat dalam memilih kata atau ungkapan untuk suatu situasi tertentu. Kesalahan ini mengacu kepada kesalahan akibat penutur tidak tepat menggunakan kaidah yang diketahui benar, bukan karena kurangnya penguasaan bahasa kedua (B2).

Corder (1967) membedakan dua macam kesalahan, yakni (1) kesalahan berbahasa yang terjadi tidak secara sistematis dalam tutur seseorang dan (2) kesalahan berbahasa yang terjadi secara sistematis pada tutur seorang yang belajar bahasa. Kesalahan berbahasa dapat terjadi dalam setiap tataran linguistik (kebahasaan). Ada kesalahan yang terjadi dalam tataran fonologi, morfologi, sintaksis, wacana dan semantik. Kesalahan berbahasa dapat disebabkan oleh intervensi (tekanan) bahasa pertama (B1) terhadap bahasa kedua (B2). Kesalahan berbahasa yang paling umum terjadi akibat penyimpangan kaidah 
bahasa. Hal itu terjadi oleh perbedaan kaidah (struktur) bahasa pertama (B1) dengan bahasa kedua (B2). Selain itu kesalahan terjadi oleh adanya transfer negatif atau intervensi B1 pada B2. Dalam pengajaran bahasa.

Menurut Tarigan dan Tarigan (1989), kesalahan berbahasa erat kaitannya dengan pengajaran bahasa, baik pengajaran bahasa pertama maupun pengajaran kedua. Kesalahan berbahasa tersebut mengganggu pencapaian tujuan pengajaran bahasa. Ada empat pengklasifikasian taksonomi kesalahan berbahasa yang dikemukakan Tarigan dan Tarigan (1989), antara lain: (1) taksonomi kategori linguistik; (2) taksonomi strategi permukaan;(3) taksonomi komparatif dan (4) taksonomi efek komunikatif. Analisis kesalahan struktur kalimat berdasarkan hasil tes keterampilan menulis yang dilaksanakan oleh peserta diklat HSK 3 Guru bahasa Mandarin SMA/SMK di PPPPTK BOE Malang tersebut bertujuan untuk mengetahui penyebab kesalahan, sehingga dapat menghasilkan rekomendasi metode pembelajaran yang sesuai untuk meningkatkan keterampilan menulis peserta didik.

Hasil penelitian relevan pernah dilakukan oleh Wikarti (2015:21) tentang kesalahan struktur frasa subordinatif bahasa Mandarin siswa kelas 3 Sastra Cina, Fakultas IImu Budaya, Universitas Indonesia. Hasil penelitian menunjukkan bahwa lima jenis kesalahan ditemukan yaitu berupa tambahan, kelalaian, kesalahpahaman, kesalahan pemilihan, dan campuran. Kelalaian adalah kesalahan paling sering yang muncul. Kurangnya pemahaman tentang frasa bawahan dari bahasa Cina adalah alasan paling umum dari kesalahan tersebut. Untuk mengurangi kesalahan, siswa harus meningkatkan pengetahuan dan kompetensi mereka tentang frasa bahasa Mandarin yang lebih rendah. Mereka harus meningkatkan latihan dan penerapan frasa juga.

Kemudian, penelitian tentang kesalahan penggunaan bahasa Mandarin juga pernah dilaksanakan oleh Trihardini (2015:7) yaitu tentang kesalahan penggunaan kata bantu bilangan bahasa Mandarin pada siswa Indonesia tingkat prapemula. Hasil penelitian ini menunjukkan bahwa terdapat kesalahan pada siswa Indonesia dalam menggunakan kata-kata Mandarin. Beberapa kesalahan tersebut yaitu: kelalaian, kesalahan pemilihan, misordering, dan campuran. 
Selanjutnya, penelitian ini membuktikan bahwa ada kesalahan sistematis yang dibuat oleh siswa dengan bahasa ibu yang berbeda dan pada tingkat yang sama dalam belajar bahasa Mandarin. Hasil penelitian ini dapat digunakan untuk mengembangkan teknik pengajaran kata-kata Mandarin yang diukur berdasarkan analisis kesalahan.

Dari beberapa hasil hasil penelitian di atas, dapat diinformasikan bahwa kajian tentang analisis kesalahan struktur kalimat pada tes keterampilan menulis dalam Diklat HSK 3 (汉语水平考试) guru bahasa Mandarin SMA/SMK di PPPPTK Boe Malang, belum dilakukan. Dengan harapan memberikan masukan dalam perbaikan pengajaran bahasa Mandarin sebagai bahasa kedua yang diukur berdasarkan analisis kesalahan.

\section{B. Metode Penelitian}

Penelitian ini dilakukan mengacu kepada taksonomi kesalahan komparatif, dimana kesalahan dibedakan menjadi: (1) kesalahan interlingual disebut juga kesalahan interferensi, yakni: kesalahan yang bersumber (akibat) dari pengaruh bahasa pertama (B1) terhadap bahasa kedua (B2) dan (2) kesalahan intralingual adalah kesalahan akibat perkembangan. Kesalahan berbahasa bersumber dari penguasaan bahasa kedua (B2) yang belum memadai.

Metodologi penelitian ini menitikberatkan pada penelitian deskriftif kualitatif dimana penelitian dilakukan dengan cara mencatat data-data yang berwujud hasil tes keterampilan menulis peserta diklat HSK 3. Tujuannya adalah menggambarkan secara sistematik fakta untuk dilakukan analisis sehingga diketahui penyebab kesalahan dan memberikan rekomendasi metode pembelajaran yang sesuai.

Subjek penelitian terdiri dari 34 guru bahasa Mandarin SMA/SMK yang mengikuti diklat HSK 3 dengan latar belakang pemerolehan bahasa Mandarin yang beragam, yaitu sebanyak 8 orang guru bahasa Mandarin dengan latar belakang Pendidikan S1 bahasa Mandarin dan sebanyak 26 peserta diklat merupakan guru alih fungsi dengan latar belakan pendidikan bukan bahasa Mandarin namun memiliki kemampuan bahasa Mandarin tingkat dasar. 
Analisis kesalahan yang dilaksanakan dengan langkah-langkah, dimulai dengan pengumpulan data, identifikasi kesalahan, analisis kesalahan, dan rekomendasi. Pengumpulan data berupa meliputi 2 (dua) yaitu data diri peserta diklat yang bersumber dari konfirmasi data peserta dan data berupa hasil tes keterampilan menulis peserta diklat HSK 3. Diklat HSK 3 berlangsung selama 12 hari efektif dan peserta melaksanakan simulasi tes HSK sebanyak 6 kali,dimana tes keterampilan menulis pada setiap simulasi tes HSK 3 terdapat 5 soal, sehingga terkumpul 30 soal tes keterampilan menulis yaitu menyusun kosakata acak menjadi kalimat yang sesuai tata bahasa Mandarin.

Langkah identifikasi kesalahan dengan melakukan identifikasi kesalahan berdasarkan data hasil tes keterampilan menulis peserta diklat HSK 3, diklasifikasi dan dikelompokan sehingga diketemukan terdapat 5 (lima) soal dengan tingkat kesalahan tertinggi. Kemudian, langkah analisis kesalahan dengan menggunakan taksonomi komparatif yaitu menganalisis penyebab kesalahan apakah termasuk pada kategori kesalahan interlingual atau kesalahan interferensi, yang mana kesalahan bersumber (akibat) dari pengaruh bahasa pertama (dalam hal ini bahasa Indonesia) terhadap bahasa kedua (dalam hal ini bahasa Mandarin). Penyebab lain terjadinya kesalahan juga adalah menganalisis kesalahan berbahasa yang bersumber dari penguasaan bahasa kedua (dalam hal ini bahasa Mandarin) yang belum memadai. Langkah terakhir yaitu rekomendasi, dengan berdasarkan hasil analisis kesalahan membuat rekomendasi metode pembelajaran yang sesuai guna meningkatkan keterampilan menulis.

\section{Hasil Penelitian dan Pembahasan}

\section{Hasil Penelitian}

Berdasarkan hasil identifikasi dan klasifikasi kesalahan hasil tes keterampilan menulis yang terdapat pada soal HSK 3 diketahui bahwa terdapat 5 (lima) soal dimana peserta paling banyak melakukan kesalahan, Soal tes keterampilan menulis pada HSK 3 berupa soal menuliskan kembali aksara Han (汉字) dimana peserta disajikan beberapa kosakata acak untuk disusun menjadi kalimat yang sesuai dengan kaidah tata Bahasa Mandarin. Kosakata yang 
disajikan berupa aksara Han (汉字) yang tidak dilengkapi dengan cara membacanya (汉语拼音) dan tidak dilengkapi dengan artinya.

Adapun 5 (lima) soal dengan tingkat kesalahan tertinggi adalah sebagai berikut:

(1) 每天 差 五分 八点 我 去 上班 坐地铁。

(2) 爸爸工作了在 银行 两年 以前。

（3）想明天 买我一本词典汉语。

(4) 那位爸爸英语老师的是教 我。

(5) 你的身体越吃甜越胖。

Adapun presentase struktur kalimat pada tes keterampilan menulis dalam diklat HSK 3 (汉语水平考试) guru bahasa Mandarin SMA/SMK di PPPPTK Boe Malang sebagai berikut :

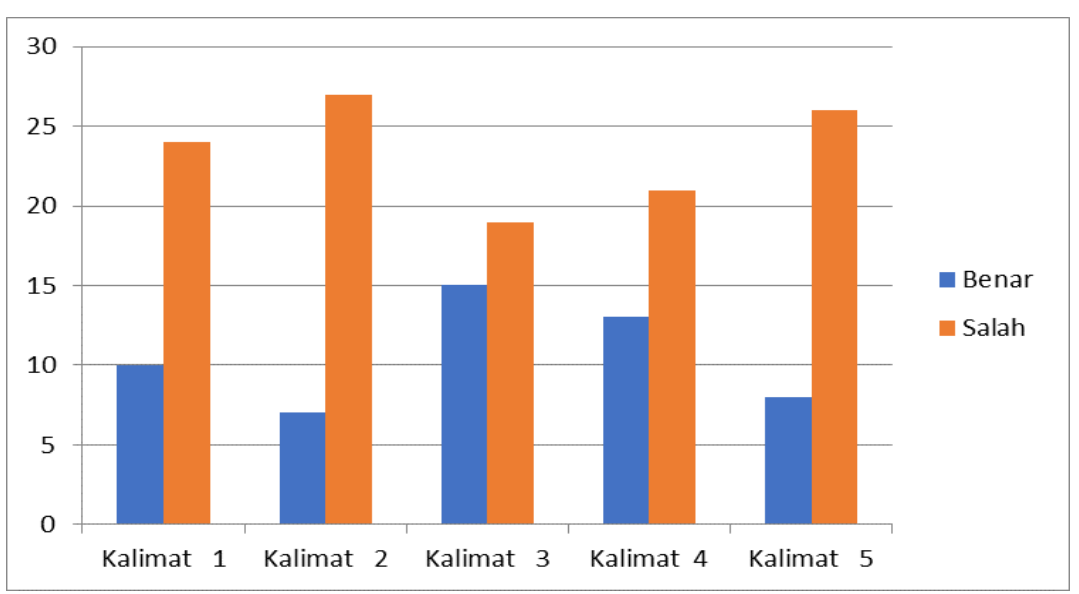

Gambar 1. Presentase Struktur Kalimat pada Tes Keterampilan Menulis dalam Diklat

HSK 3 (汉语水平考试) Guru Bahasa Mandarin SMA/SMK di PPPPTK Boe Malang

Dari gambar di atas, dapat dijelaskan beberapa kesalan struktur kalimat pada tes keterampilan menulis dalam Diklat HSK 3 (汉语水平考试) guru bahasa Mandarin SMA/SMK di PPPPTK Boe Malang, sebagai berikut.

1. Pada kalimat pertama terdapat 24 orang peserta menjawab salah, 10 orang peserta menjawab benar.

2. Pada kalimat kedua, terdapat 27 orang peserta menjawab salah dan 7 orang peserta menjawab benar.

3. Pada kalimat ketiga, terdapat 19 orang peserta menjawab salah dan 15 orang peserta menjawab benar. 
4. Pada kalimat keempat, terdapat 21 orang peserta menjawab salah dan 13 orang peserta menjawab benar.

5. Pada kalimat kelima, terdapat 26 orang peserta menjawab salah dan 8 orang peserta menjawab benar.

\section{Pembahasan}

Berdasarkan hasil analisis kesalahan ditemukan sebagai berikut:

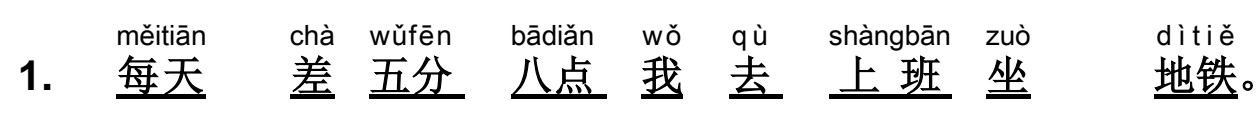

Setiap hari kurang 5 menit jam 8 saya pergi kerja naik kereta.

Susunan kalimat sesuai tata Bahasa Mandarin yang benar adalah sebagai berikut:

我每天差五分八点坐地铁去上班。

Saya setiap hari kurang lima menit jam 8 naik kereta pergi kerja.

Akan tetapi berdasarkan data hasil tes menunjukan 24 orang peserta menjawab menggunakan susunan kalimat sesuai tata Bahasa Indonesia sebagai berikut:

每天 8 点差五分我去上班坐地铁。(kesalahan interferensi)

Setiap hari jam 8 kurang 5 menit saya pergi kerja naik kereta bawah tanah.

Kesalahan interfensi terutama terletak pada 2 hal yaitu :

1. Penerapan waktu:jam Jam 7.55 dalam konteks kalimat 1 (satu) tertulis jam 8 kurang 5 menit dimana dalam tata bahasa Indonesia tertulis 8 点差五分 sementara kaidah tata Bahasa Mandarin yang benar adalah 差五分八点。

2. Penerapan struktur kalimat

Dalam konteks kalimat pergi kerja naik kereta bawah tanah, peserta menuliskan sesuai kaidah tata Bahasa Indonesia yaitu 去上班坐地铁 
sementara kaidah tata Bahasa mandarin yang benar seharusnya adalah 坐地铁去上班。

Pola tata Bahasa mandarin yang sederhana adalah sebagai berikut:

\begin{tabular}{|c|c|c|c|}
\hline \multicolumn{3}{|c|}{ Naik Apa } & Pergi Kemana \\
\hline 坐 & 地铁 & 去 & 上班。 \\
\hline 坐 & 飞机 & 去 & 旅游。 \\
\hline \multicolumn{3}{|c|}{ Pesawat } & tamasya. \\
\hline 坐 & 车 & 去 & 上课。 \\
\hline & Mob & & sekolah \\
\hline
\end{tabular}

2. 爸爸 亖作 品 在 银行 两年以前。

$\underline{\text { Ayah bekerja (pernah) }} \underline{\text { di }}$ bank $\underline{2 \text { tahun }}$ dulu.

Susunan yang tepat sesuai tata Bahasa Mandarin adalah sebagai berikut: 爸爸以前在银行工作了两年。

Ayah dulu di bank berkerja pernah dua tahun.

Akan tetapi, berdasarkan hasil tes peserta terdapat variasi jawaban peserta antara lain sebagai berikut:

a. Kesalahan interferensi dimana susunan kalimat menggunakan tata Bahasa Indonesia yaitu:

以前爸爸了两年工作在银行。

Dulu ayah pernah 2 tahun bekerja di bank.

b. Kesalahan intralingual dimana terdapatnya kurangnya pemahaman penggunaan tata Bahasa dalam konteks kata “在”dan kata “了”, sehingga diketemukan jawaban peserta sebagai berikut: 
1) 爸爸以前在银行工作两年了。

Ayah dulu di bank bekerja dua tahun pernah.

2) 爸爸以前工作在银行两年了。

Ayah dulu bekerja di bank dua tahun pernah.

3) 以前在银行爸爸工作两年了。

Dulu di bank ayah kerja dua tahun pernah.

Kata " 在 "diterjemahkan dalam Bahasa Indonesia menjadi kata"di". Penggunaan kata “在”dalam Bahasa Mandarin berbeda dengan penggunaan dalam tata Bahasa Indonesia:

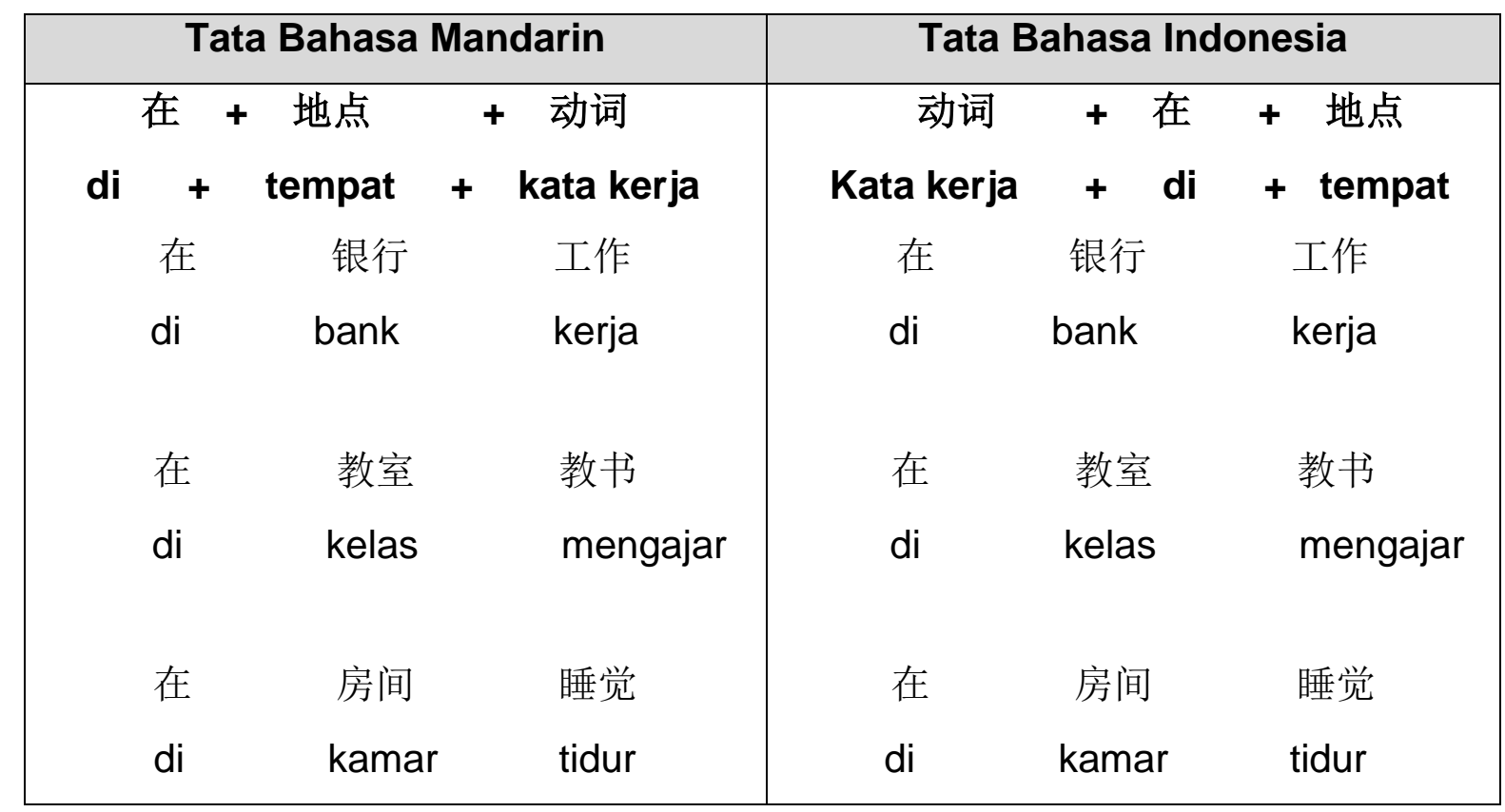

Kata "了" dalam tata bahasa Mandarin memiliki penggunaan yang sangat variatif, akan tetapi pemahaman peserta masih pada tahap "了"digunakan diakhir kalimat yang memiliki arti lampau / sudah pernah terjadi. Penggunaan "了"dalam bahasa Mandarin soal nomor 2 (dua) adalah menyatakan peristiwa yang pernah terjadi di masa lampau. Struktur tata Bahasa mandarin yang benar adalah sebagai berikut. 


$$
\begin{aligned}
& \text { 工作 了两年 } \\
& \text { Kata kerja }+了+\text { keterangan waktu (durasi) } \\
& \begin{array}{ccccc}
\text { xiăng míngtiān măi wo } & \text { wi běn cídiăn hànyŭ } \\
\text { 3. 想 明天 } & \text { 买 我 一本 词典 汉语。 }
\end{array}
\end{aligned}
$$

Ingin besok membeli saya sebuah kamus Bahasa mandarin

Susunan yang tepat sesuai tata Bahasa Mandarin adalah sebagai berikut:

(明天) 我（明天）想买一本汉语词典。

(Besok) saya (Besok) ingin membeli sebuah Bahasa mandarin kamus.

Susunan sesuai tata Bahasa Indonesia adalah sebagai berikut :

（明天）我（明天）想买一本词典汉语（明天）。

(besok) saya (besok) ingin membeli sebuah kamus Bahasa mandarin (besok).

Pada soal no.3 tersebut ditemukan kesalahan interfensi akibat adanya pengaruh bahasa pertama pada frasa Diterangkan Menerangkan seperti berikut:

\begin{tabular}{|c|c|c|}
\hline Universitas Indonesia & $\begin{array}{l}\text { dàxué yinn i } \\
\text { 大学印尼 }\end{array}$ & $\begin{array}{l}\text { yinn i dàxué } \\
\text { 印尼 大学 }\end{array}$ \\
\hline Guru Bahasa inggris & $\begin{array}{l}\text { lăoshī yīngy ú } \\
\text { 老师 英语 }\end{array}$ & $\begin{array}{l}\text { yīngy ǔ lăoshī } \\
\text { 英语老师 }\end{array}$ \\
\hline
\end{tabular}

\section{Tata Bahasa Indonesia Tata Bahasa Mandarin}

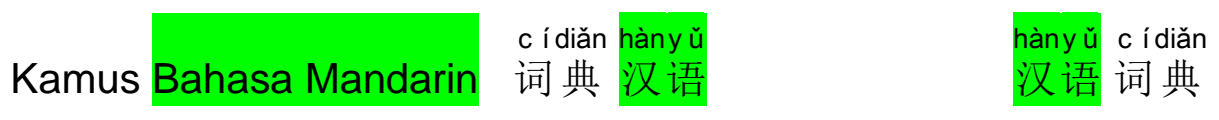

$\begin{array}{lll}\text { Ayah saya } & \text { bàba wǒ } & \text { wǒ bàbà } \\ \text { 爸爸 我 } & \text { 我 爸爸 }\end{array}$

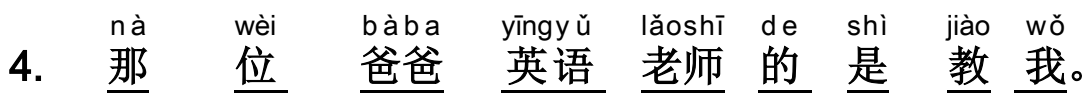

$\underline{\text { Itu }}$ (kt. Bantu bilangan) ayah Bahasa inggris guru (partikel) adalah mengajar saya. 
Susunan kalimat sesuai kaidah tata Bahasa mandarin adalah :

那位教英语的老师是我爸爸。

Itu mengajar Bahasa inggris guru adalah saya ayah

Susunan kalimat sesuai kaidah tata Bahasa Indonesia adalah:

老师英语那位是爸爸我。

Guru bahasa inggris itu adalah ayah saya.

Dalam tata Bahasa Indonesia, kata bantu bilangan “位”yang digunakan untuk guru dan partikel “的”dalam konteks kalimat diatas dapat dihilangkan atau tidak digunakan, sehingga banyak ditemukan kesalahan letak 位 dan 的 akibat kurang menguasai bahasa kedua. Namun pada konteks frasa DM, peserta banyak melakukan kesalahan interferensi akibat pengaruh tata Bahasa Indonesia, seperti halnya pada soal no. 4 di atas.

5. 你 的 身体越吃 甜 越 胖。

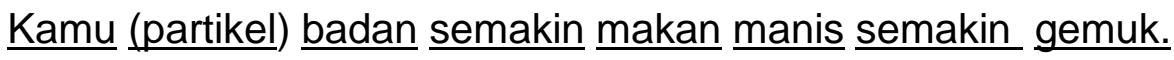

Dalam tata Bahasa mandarin struktur kalimat yang tepat adalah: 你越吃甜的身体越胖。

Kamu semakin makan manis badan semakin gemuk.

Dalam tata Bahasa Indonesia struktur kalimatnya adalah:

越你吃甜的身体越胖。

Semakin kamu makan manis badan (kamu ) semakin gemuk

Hasil analisis kesalahan ditemukan kesalahan interlingual yang disebabkan kurangnya penguasaan terhadap Bahasa kedua dalam hal ini adalah bahasa mandarin terutama dalam penggunaaan kata “越...越.....”sehingga kesalahan jawaban yang diberikan pesertapun bervariatif antara lain: 

a. 你的身体越吃甜越胖。
b. 你的身体吃越甜越胖。
C. 你吃的越甜身体越胖。

\section{Simpulan}

Berdasarkan taksonomi komparatif, hal ini disebabkan adanya kesalahan interferensi dimana kesalahan bersumber karena adanya pengaruh tata bahasa pada bahasa pertama yaitu bahasa Indonesia kepada bahasa kedua yaitu bahasa Mandarin. Berikut adalah perbandingan struktur kalimat bahasa Indonesia dengan struktur kalimat bahasa Mandarin:

(1) Struktur kalimat dalam bahasa Indonesia (印尼语的句子词序)
（状语）＼cjkstart主语
谓语
宾语 ( 定语-补语一状语 )
(Keterangan) Subjek
Predikat
Objek (keterangan)

(2) Struktur kalimat dalam bahasa Mandarin (汉语的句子词序)

(定语) [状语] 主语 [状语] 谓语 (定语) <补语> 宾语 <补语>

(Keterangan) Subjek (Ket.) Predikat (Keterangan) Objek (Keterangan)

Selain kesalahan interferensi, analisis kesalahan dalam menjawab soal disebabkan adanya kesalahan intralingual dimana peserta belum menguasai Bahasa kedua seutuhnya, terutama dalam pemahaman terkait dengan materi sebagai berikut:

a. penggunaan kata keterangan waktu berupa penulisan jam : 差、分、点、等;

b. penggunaan kata keterangan waktu : 以前、明天;

c. penggunaan preposisi 在;

d. penggunaan partikel 了;

e. penggunaan kata sambung 越.....越.....;

f. penggunaan partikel 的' dan

g. pola diterangkan menerangkan. 


\section{Daftar Pustaka}

Corder, Pit S. (1982). Eror Analysis and Interlanguage. England, UK: Oxford University Press.

Corder, Pit. (1967). The Significance of Learner's Errors. International Review of Applied Linguistics, 161-170.

Javed, M., Juan, Wu Xiao, Nazli, Saima. (2013). "A Study of Students' Assessment in Writting skills of the English Language". International Journal of Instruction, 6(2). www.e-ji.net . Diakses tanggal 10 November 2018 .

Pateda, Mansur. (1989). Analisis Kesalahan. Ende: Arnoldus.

Tarigan, Henry Guntur dan Djago Tarigan. (1989). Pengajaran Analisis Kesalahan Berbahasa. Bandung: Angkasa.

Trihardini, A. (2015). Kesalahan Penggunaan Kata Bantu Bilangan Bahasa Mandarin pada Siswa Indonesia Tingkat Prapemula. Lingua Cultura, 9(1), 7. doi:10.21512/lc.v9i1.755

Wikarti, A. R. (2015). Kesalahan Struktur Frasa Subordinatif Bahasa Mandarin. Lingua Cultura, 9(1), 21. doi:10.21512/lc.v9i1.757 